\title{
Water Quality and Productivity of Dryland Catfish Pond Based on Existing Technology and Land Priority in Gunungkidul
}

\author{
Nur Indah Septriani ${ }^{1}$ and Rustadi $^{2}$ \\ ${ }^{1}$ Environmental Science, Gadjah Mada University, Yogyakarta, Indonesia \\ ${ }^{2}$ Fisheries Department, Agricultural Faculty, Gadjah Mada University, Indonesia \\ Correspondence to: indah_bio07@yahoo.com
}

\begin{abstract}
Nur Indah Septriani and Rustadi. 2015. Water Quality and Productivity of Dryland Catfish Pond Based on Existing Technology and Land Priority in Gunungkidul. Aquacultura Indonesiana, 16 (2): 56-62. This research is aimed to examine the water quality and productivity of dryland catfish pond based on the existing technology and land priority in Gunungkidul. Samples from nine ponds employing intensive, extensive, and semi-intensive technology in high priority land, middle priority land and low priority land so that there were nine ponds of sample (high priority land with intensive technology or PTI, high priority land with extensive technology or PTE, high priority land with semi-intensive technology or PTS, non-priority land with intensive technology or NPI, non-priority land with extensive technology or NPE, non-priority land with semi-intensive technology or NPS, middle priority land with intensive technology or PSI, non-priority land with extensive technology or PSE, and middle priority land with semi-intensive technology or PSS) analysed to find out the water quality such as the ammonia, nitrate, and nitrite contents; $\mathrm{pH}$; DO; temperature and turbidity; land productivity; and profit. To find out the productivity analyzed from initial stock density and the number of crops. Analysis of data used scoring of water quality and productivity. The highest sample ponds will be suggested as a model for technology applied in Gunungkidul Regency. Generally the water quality of catfish ponds in Gunungkidul was high ammonia, DO in nonpriority land was the lowest level. Turbidity in nonpriority pond was not good because the water resources contain much $\mathrm{CaCO}_{3}$ from karst rock. While, the other water quality parameters, such as nitrate, nitrite, $\mathrm{pH}$ and temperature was good standard for catfish farming development. The highest water quality and productivity was PTI pond whose score 0.96 and productivity $11.67 \mathrm{~kg} / \mathrm{m}^{2}$. The lowest water quality and productivity was PSE pond whose score 0.6 and productivity $0.83 \mathrm{~kg} / \mathrm{m}^{2}$. Therefore, high land priority using intensive technology was the most effective to develop catfish farming in Gunungkidul Regency.
\end{abstract}

Keywords: Dryland catfish pond; Existing technology; Land priority; Productivity; Water quality

\section{Introduction}

In the previous study, carrying capacity of marginal land in dryland catfish farming in Gunungkidul Regency based on biophysical and socio-economic characteristics had already been analyzed. The result showed that there were three categories of land for catfish farming, namely, high priority, medium priority and non-priority land or conservatory priority. High priority areas include the sub-districts of Playen, Wonosari, Semanu, Paliyan, Karangmojo, Semin, and Ngawen. The medium priority areas include the sub-districts of Tanjungsari, Nglipar, Ponjong, Gedangsari, Patuk, Girisubo and Saptosari. Meanwhile, areas prioritized for water conservation comprise the sub-districts of Rongkop, Purwosari and Panggang (Septriani et al., 2015).

Highly prioritized lands are mostly in Ledok Wonosari in which the characteristics are close water sources, flat topography, and short distance to the center of local government; therefore, the people are of high economic status.
Medium priority land is generally characterized by close water sources but hilly topography. Nonpriority land is generally characterized by far water sources and hilly topography. Figure 1 shows the map of priority land for catfish farming development.

Based on the existing technology, findings related to the application of technology is not quite compatible with the land potential. Therefore, for optimizing the budget, attention to the development of catfish farming based on the land potential must be given. The distribution of the fish farming groups (Pokdakan) is not proportional with the land potential. However, in Playen subdistrict, it suit well with the land potensial, as this sub-district is designated as the area for the pilot project of minapolitan (fishery zone). Meanwhile, many Pokdakans in other sub-districts are laid off. Therefore, it is also necessary to prioritize the catfish aquaculture development based on the carrying capacity (land potential). 


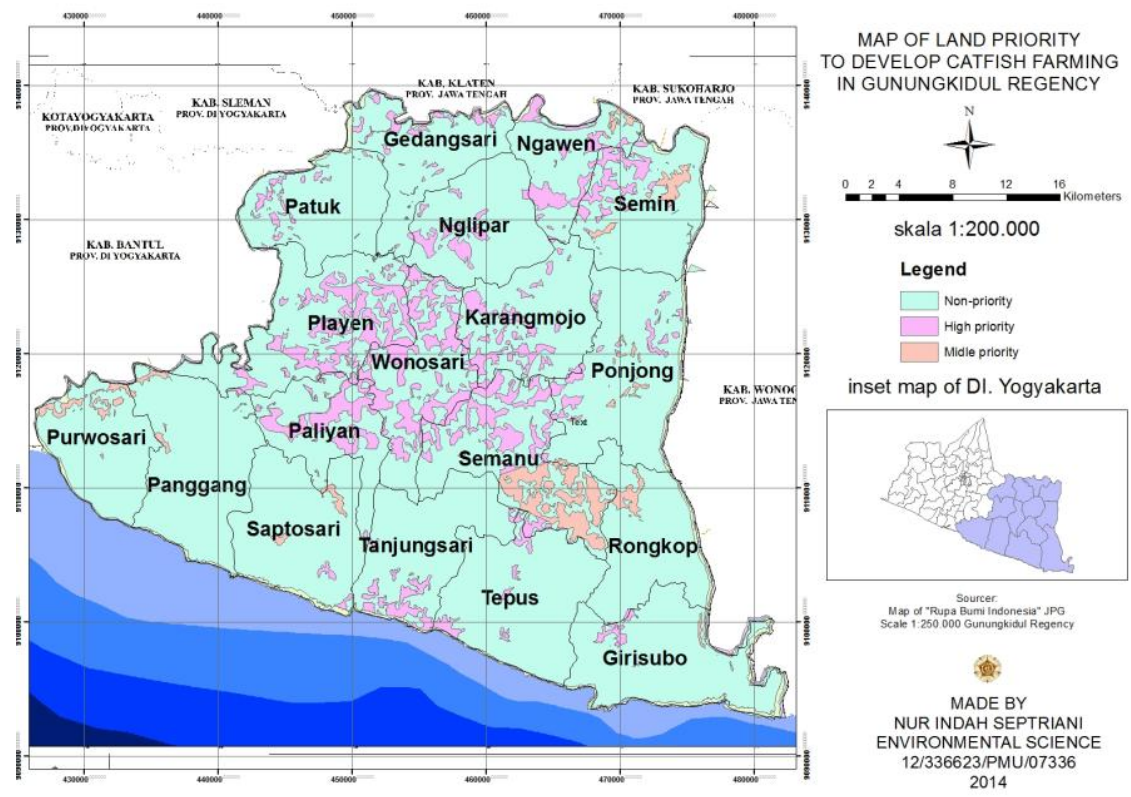

Figure 1. Land priority map for catfish farming in Gunungkidul

Apart from the land priority, based on the existing technology, which is divided into intensive, semiintensive and non-extensive. The explanation of those technologies describes in Table 2.

Table 1. Technology catfish farming based on existing

\begin{tabular}{llllll}
\hline No & Sistem & \multicolumn{3}{c}{ Characteristics } \\
\hline & & Stock density $/ \mathrm{m}^{2}$ & Feed giving & Market networking & Water treatment \\
\cline { 3 - 5 } 1 & Extensive & $1-99$ & $0-2 \mathrm{X}$ & No/limited & No \\
2 & Semi Intensive & $100-149$ & $2-3 \mathrm{X}$ & Yes/permanent & Sometimes \\
3 & Intensive & $150-1000$ & $3-6 \mathrm{X}$ & Wide & Always \\
\hline
\end{tabular}

However, the technology has not been implemented in favorable site yet, so the impact is not proportional to the technology applied. For example, extensive technology is implemented in an area which has far water sources and in low social economic supporting. As a consequence, pond water quality is not improved and the productivity could not been optimal.

The overall performance of an aquaculture system is partly determined by its water quality. Stresses from poor water quality will adversely affects fish growth causing low production, profit and product quality (Shoko et al., 2014). A research about technology and water quality in catfish pond has been done by Rohmana et al. (2015) who used catfish co-culture with prawns. They state that the water quality of catfish-prawn coculture with organic carbon addition was generally better than catfish monoculture. Coculture with prawn with carbon source addition in catfish culture also resulted in significantly lower total Food Conversion Ratio (FCR) and significantly higher nitrogen utilization. The overall results suggest that catfish co-culture with prawn with organic carbon addition would minimize nitrogen residue and also generate additional income for catfish farmer. Townsend and Baldisserotto (2001) examine fingerlings of silver catfish, Rhamdia quelen, in water with different $\mathrm{pH}$ and hardness values $(30,70,150$, 300 and $600 \mathrm{mg} / \mathrm{L} \quad \mathrm{CaCO}_{3}$ ). There was no mortality of fingerlings exposed to $\mathrm{pH} 4.0,7.0$, and 9.5 at all hardness levels. The hardness levels studied did not affect the survival of silver catfish fingerlings exposed to $\mathrm{pH} 3.5,4.0,7.0$, and 9.5 for $96 \mathrm{~h}$. However, the increase of water hardness improved the survival of fingerlings of this species exposed to $\mathrm{pH} 3.75,10.0$, and 10.5. Therefore, hardness and $\mathrm{pH}$ was important to be measured in catfish ponds, especially when in fingerlings phase.

Monitoring the water quality in fish farming is very necessary. The numerical model that may be successfully used for planning and monitoring purposes illustrates an economical solution in the management of fish farms. Water is a critical factor in the life of all aquatic species. In aquaculture, the character of water that affects the survival, reproduction, growth, or management of fish or other aquatic creatures is water quality variable (Boyd, 2003). In all culture systems, fish performs its physiological activities such as 
breathing, excretion of wastes, feeding, maintaining salt balance and reproduction in the water medium.

The overall performance of aquaculture system is partly determined by its water quality (Alam and Al-Hafedh, 2006). Poor water quality stresses and adversely affects fish growth with consequently low production, profit and product quality (Iwama et al., 2000). Production is reduced when the water contains contaminants that can bother the development, growth, and reproduction or even can cause mortality to the cultured species. As a result, fish farmers are obliged to manage the water quality so as to provide a relatively stress free environment that meets the physical, chemical and biological standards for the fish normal health and growth performance (Isyiagi et al., 2009).

The research about water quality and productivity based on land priority and existing technology for catfish pond in marginal land has not been done yet. This information is necessary to make decision about how to implement technology without any loss. That is why this research is aimed to examine water quality and productivity of dryland catfish pond based on the existing technology and land priority in Gunungkidul and to determine the suitable technology based on the land priority.

\section{Materials and Methods}

\section{Time and Location}

This research was conducted in Gunungkidul Regency in January - June 2014.

\section{Samples}

The sample of the pond based on land priority and technology used. There were nine ponds as the samples. The designing of sample ponds was described as below (Table 2.).

Table 2. Designing sample ponds

\begin{tabular}{llll}
\hline & Extensive & Semi-intensive & Intensive \\
\hline $\mathrm{Q}$ & PTE & PTS & PTI \\
Midle & PSE & PSS & PSI \\
$\begin{array}{l}\text { Priority } \\
\text { Non- Priority }\end{array}$ & NPE & NPS & NPI
\end{tabular}

\section{Water quality}

Samples from the ponds employing intensive, extensive, and semi-intensive technology were analysed to find out the water quality such as the ammonia, nitrate, and nitrite contents; $\mathrm{pH}$; DO; temperature and turbidity. The Measurement of temperature, $\mathrm{pH}, \mathrm{DO}$ and turbidity was done by Water Quality Checker, ammonia by SNI 06-6989.30-2005 method, nitrat by IK 9.5.4.1 (Spektrofotometri) method, nitrite by SNI 06-6989.9-2004 method, turbidity by SNI 06-6989.25-2005 method. The samples were taken from nine ponds by purposive random sampling. The pond tracking used GPS and land priority map to determine sample ponds (appendix 1).

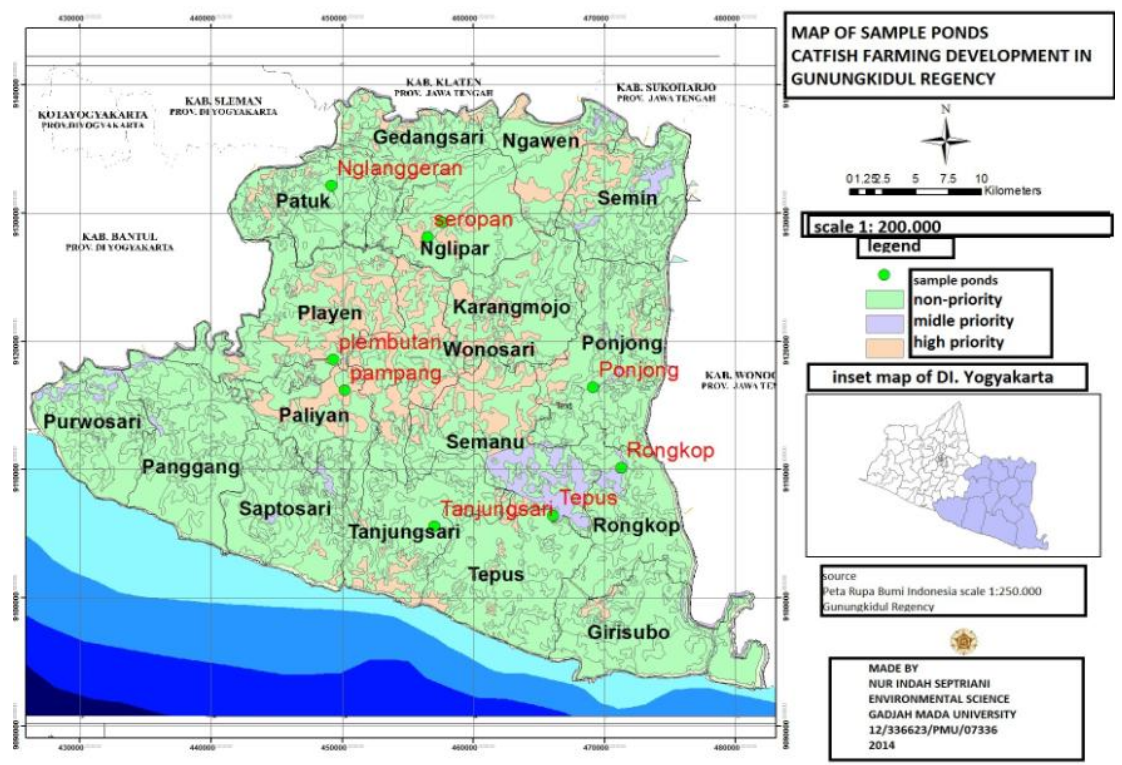

Appendix 1 


\section{Productivity}

The data of nine ponds productivity were analyzed from initial stock density and the number of crops. From those data the number of productivity $/ \mathrm{m}^{2}$ was analyzed in this research.

\section{Analysis of Data}

Analysis of data used scoring of water quality and productivity. The highest sample ponds will be suggested as a model for technology applied in Gunungkidul Regency. Standard of scoring water quality was shown in Table 3.

Table 3. Parameter that is required for catfish pond

\begin{tabular}{|c|c|c|c|c|c|}
\hline No & Parameter & Good standart (optimum) & \multicolumn{3}{|c|}{ Score } \\
\hline & & & 5 & 3 & 1 \\
\hline 1 & Amonia & $\begin{array}{l}\leq 1 \mathrm{mg} / \mathrm{L} \text { if } \mathrm{pH} 7 \text { and } \leq 10 \\
\mathrm{mg} / \mathrm{L} \text { if } \mathrm{pH} 8\end{array}$ & $<1 \mathrm{mg} / \mathrm{L}$ if $\mathrm{pH} 7$ & $1 \mathrm{mg} / \mathrm{L}$ & $>1 \mathrm{mg} / \mathrm{L}$ \\
\hline 2 & Nitrat & $\leq 20 \mathrm{mg} / \mathrm{L}$ & $<20 \mathrm{mg} / \mathrm{L}$ & $20 \mathrm{mg} / \mathrm{L}$ & $>20 \mathrm{mg} / \mathrm{L}$ \\
\hline 3 & Nitrite & $\leq 0.06 \mathrm{mg} / \mathrm{L}$ & $<0.06 \mathrm{mg} / \mathrm{L}$ & $0.06 \mathrm{mg} / \mathrm{L}$ & $>0.06 \mathrm{mg} / \mathrm{L}$ \\
\hline 4 & $\mathrm{pH}$ & $6.5-8.5$ & $6.5-8.5$ & 5-6.4 and 8.6-9 & $1-4.9$ and $9.1-14$ \\
\hline 5 & DO & $\geq 2 \mathrm{mg} / \mathrm{L}$ & $>2 \mathrm{mg} / \mathrm{L}$ & $2 \mathrm{mg} / \mathrm{L}$ & $<2 \mathrm{mg} / \mathrm{L}$ \\
\hline 6 & Turbidity & $\leq 100 \mathrm{NTU}$ & $<100 \mathrm{NTU}$ & $100 \mathrm{NTU}$ & $>100 \mathrm{mg} / \mathrm{L}$ \\
\hline 7 & Temperature & $25^{\circ} \mathrm{C}-30^{\circ} \mathrm{C}$ & $25^{\circ} \mathrm{C}-30^{\circ} \mathrm{C}$ & $20-25^{\circ} \mathrm{C}$ and $31-35^{\circ} \mathrm{C}$ & $20^{\circ} \mathrm{C}$ and $35^{\circ} \mathrm{C}$ \\
\hline
\end{tabular}

\section{Results and Discussion}

The result of water quality was shown in Figure 2 and the score of that was shown in Table 4.

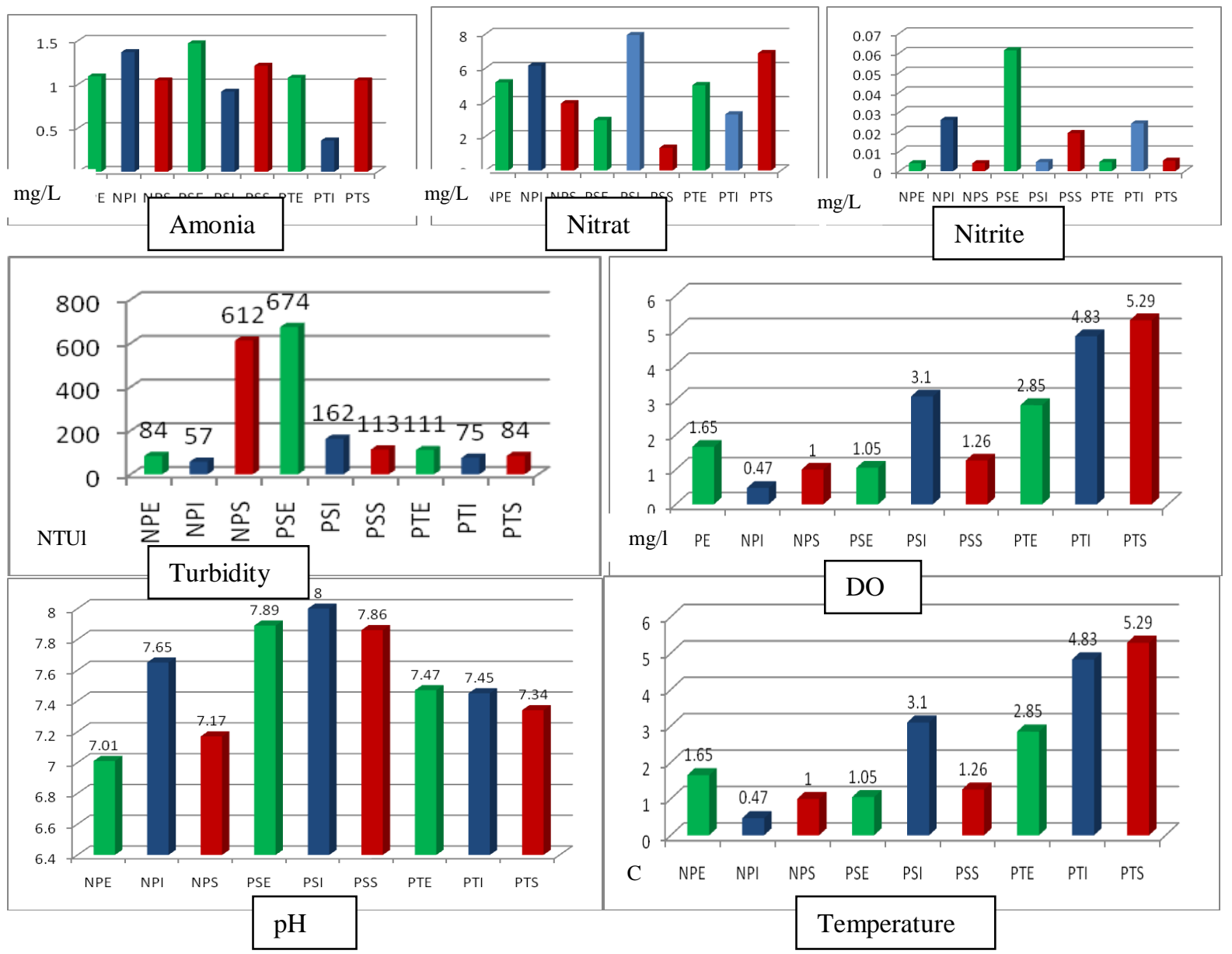

Figure 2. Water quality of dryland catfish pond in Gunungkidul 
Table 4. The score of water quality each pond

\begin{tabular}{ccccccccccc}
\hline $\begin{array}{l}\text { Pond } \\
\text { name }\end{array}$ & Amonia & Nitrat & Nitrite & Turbidity & DO & pH & Temperature & $\begin{array}{c}\text { Total } \\
\text { score }\end{array}$ & $\begin{array}{c}\text { Total } \\
\text { score }\end{array}$ & Category \\
\hline NPE & 1 & 5 & 5 & 5 & 3 & 5 & 5 & 29 & 0.82 & High \\
NPI & 1 & 5 & 5 & 5 & 1 & 5 & 3 & 27 & 0.77 & High \\
NPS & 1 & 5 & 5 & 1 & 1 & 5 & 5 & 21 & 0.6 & Midle \\
PSE & 1 & 3 & 5 & 1 & 3 & 5 & 3 & 21 & 0.6 & Midle \\
PSI & 1 & 5 & 5 & 3 & 3 & 5 & 5 & 27 & 0.77 & High \\
PSS & 1 & 5 & 5 & 3 & 3 & 5 & 5 & 27 & 0.77 & High \\
PTE & 1 & 5 & 5 & 3 & 5 & 5 & 5 & 29 & 0.82 & High \\
PTI & 3 & 5 & 5 & 5 & 5 & 5 & 5 & 33 & 0.96 & High \\
PTS & 1 & 5 & 5 & 5 & 5 & 5 & 5 & 31 & 0.86 & High \\
\hline
\end{tabular}

Free ammonia level in nine ponds had a high concentration, so it was given a score of 1 (a lowest score). This value was low because it can interfere with breathing fish, damage the gills. However, an ammonia level of PTI pond was still good for catfish because this pool applied water treatment i.e water changing regularly.

In general, the content of nitrate in the nine ponds was not influenced by the culture system but it was influenced by land potential. High-priority areas for the development of catfish showed a lower nitrate levels because the source of water comes from resources that had not been contaminated by agricultural waste, so that the land potential was influential even though the technology applied was poor. In general, the content of nitrate in the nine ponds was still appropriate for catfish farming. Nitrate level of more than $20 \mathrm{mg} / \mathrm{L}$ was given the lowest score (1) because it could potentially lead to eutrophication.

In general the nitrite content had low value, while the ammonia content was high enough. In normal condition of nitrogen cycle in aquaponic system, ammonia will be changed to nitrite by nitrosomonas bacteria (Figure 3 ). It demonstrated the process of ammonia to nitrite in the nitrogen cycle system was not perfect. It could be caused by bacteria nitrosomonas which convert ammonia to nitrite did uneffectively. The nitrite level in PSE pond was high because water treatment was not done. Nitrite level more than 0.06 $\mathrm{mg} / \mathrm{L}$ could result in fish death therefore nitrite

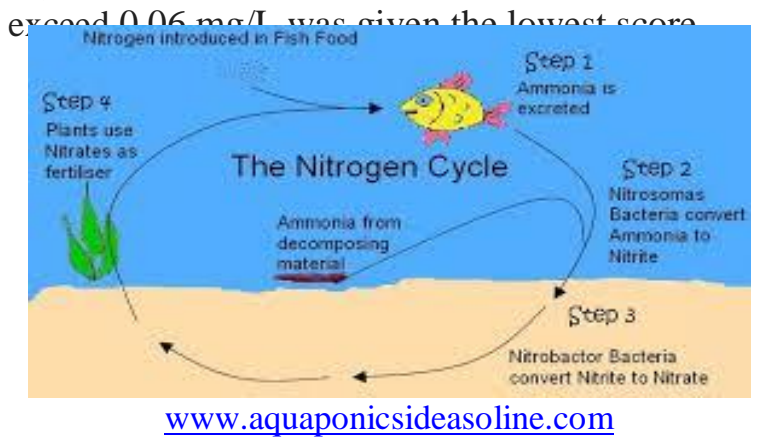

Figure 3. Nitrogen Cycle in Environmental Aquatic
Turbidity in PSE pond reached 612 NTU because water treatment technology had not been able to deal with water quality problems that contained a lot of dissolved inorganic substances. This was also due to a sampling area taken from the non-priority land, karst hill, contained high turbidity of water resources. Turbidity in NPS pond reached 674 NTU, but it showed solid green, meaning that were many organic contents. High organic content was due to the rich content of ammonia, nitrate and nitrite in those waters, causing alga to bloom. So the content of ammonia, nitrate and nitrite must be reduced by improving water treatment technology.

Catfish ponds that had the highest Dissolved Oxygen (DO) were performed by semi-intensive and intensive technology in high priority land. High DO content occurred because the technology of semi-intensive and intensive used organic feed so it could maintain water quality, as well as good quality of water resources. The lowest DO existed in an area of non-priority development of catfish with intensive system (NPI pond), whose number was $0.47 \mathrm{mg} / \mathrm{L}$. Low DO occured due to high stocking density and feeding intensively 5-6 times daily $\left(3 \mathrm{~kg} /\right.$ feed for $\left.250 / \mathrm{m}^{2}\right)$. Figure 4 Showed NPI pond in low level DO.

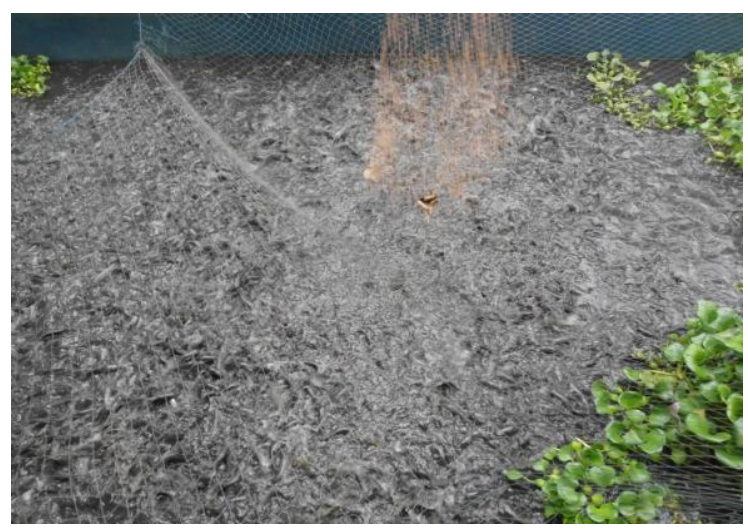

Figure 4. NPI pond in low level DO (dark water). 
$\mathrm{pH}$ of pond water in Gunungkidul fulfilled the requirements of the growth of catfish (7.01-8). This value describe that $\mathrm{pH}$ tend to basa (alkali) because this area was mostly composed of karst rocks containing $\mathrm{CaCO} 3$ (lime). The content of calcium could stabilize the $\mathrm{pH}$. In general all the sample ponds got high scores (5) for the $\mathrm{pH}$ value.

In general, the temperature of the pond water was still appropriate for catfish farming although there was a pond that had a rather high temperature of more than 32 degree celsius. A pond that had an optimum temperature for catfish farming 25-30 degree celsius had a high score (5).

Generally the water quality of catfish ponds in Gunungkidul was high ammonia level caused by food residue, contaminant from fertilizer surround water resources. DO in nonpriority land was the lowest level because limited number of water resources so that the ponds cannot change water regularly. Turbidity in nonpriority pond was not good because the water resources contain much $\mathrm{CaCO}_{3}$ from karst rock. While, the other water quality parameters, such as nitrate, nitrite, $\mathrm{pH}$ and temperature was good standard for catfish farming development

High water quality was not always high in productivity, for example, even though NPE pond had higher water quality than PSI pond, the productivity of this pond was lower than PSI pond. Even though NPS, PSS and PSI had higher water quality than PTE and PTS pond. The productivity of those ponds was lower than PTE and PTS pond. It showed that the technology applied in NPE, NPS, PSS and PSI had not been optimal. It could be optimilized by increasing stocking density. Table 5 showed the productivity each pond and Figure 5 showed interrelation between water quality and productivity.

Table 5. The productivity of each pond

\begin{tabular}{ccccccc}
$\begin{array}{c}\text { Pond } \\
\text { name }\end{array}$ & $\begin{array}{c}\text { Wide of } \\
\text { pond }\left(\mathbf{m}^{2}\right)\end{array}$ & $\begin{array}{c}\text { number of } \\
\text { stocking }\end{array}$ & Stock density/ $\mathbf{~ m}^{\mathbf{2}}$ & $\begin{array}{c}\text { Harvest } \\
\mathbf{( k g})\end{array}$ & $\begin{array}{c}\text { productivity/ } \\
\mathbf{m}^{\mathbf{2}}\end{array}$ & $\begin{array}{c}\text { Productivity } \\
(\mathbf{\%})\end{array}$ \\
\hline NPE & 17.5 & 1,225 & 70 & 100 & 5.71 & 23 \\
NPI & 50 & 12,500 & 250 & 515 & 10.30 & 41 \\
NPS & 12 & 1,200 & 100 & 100 & 8.33 & 33 \\
PSE & 12 & 600 & 50 & 10 & 0.83 & 3 \\
PSI & 12 & 1,200 & 150 & 59 & 4.92 & 20 \\
PSS & 8 & 960 & 120 & 80 & 10.00 & 40 \\
PTE & 15 & 1,200 & 80 & 100 & 6.67 & 27 \\
PTI & 30 & 6,000 & 200 & 350 & 11.67 & 47 \\
PTS & 15 & 1,500 & 100 & 120 & 8.00 & 32 \\
\hline
\end{tabular}

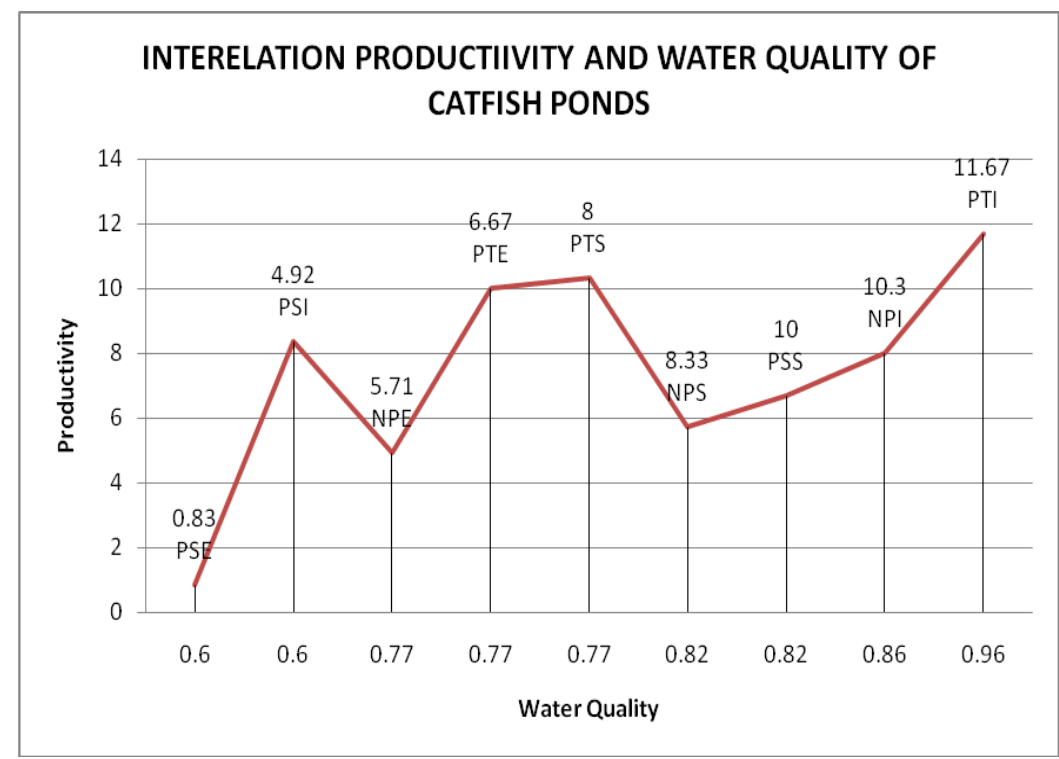

Figure 5. interrelation between water quality and productivity

The highest water quality and productivity was PTI pond whose score 0.96 and productivity $11.67 \mathrm{~kg} / \mathrm{m}^{2}$. The lowest water quality and productivity was PSE pond whose score 0.6 and productivity $0.83 \mathrm{~kg} / \mathrm{m}^{2}$. 


\section{Conclusion}

Generally the water quality of catfish ponds in Gunungkidul was high ammonia, DO in nonpriority land was the lowest level. Turbidity in nonpriority pond was not good because the water resources contain much $\mathrm{CaCO}_{3}$ from karst rock. While, the other water quality parameters, such as nitrate, nitrite, $\mathrm{pH}$ and temperature was good standard for catfish farming development. The highest water quality and productivity was PTI pond whose score 0.96 and productivity $11.67 \mathrm{~kg} / \mathrm{m}^{2}$. The lowest water quality and productivity was PSE pond whose score 0.6 and productivity $0.83 \mathrm{~kg} / \mathrm{m}^{2}$. Therefore, high land priority using intensive technology was the most effective to develop catfish farming in Gunungkidul Regency.

\section{Acknowledgement}

The authors would like to thank DIKTI for funding this research. Mr. Riptanto Edi Widodo, Mr. Deddy Budiono, Mr. Anjal Anie Asmara, Mr. Adhita Sri Prabakusuma, Dr.Titik Soegiharto, Mr., Prof. Rustadi and Dr. Eko Haryono who help the researcher to collect data and to consult the research concept.

\section{References}

Alam, A. and Y.S. Al-Hafedh. 2006. Diurnal dynamics of water quality parameters in an aquaculture system based on recirculating green water technology. J. Appl. Sci. Environ. Manage., 10:19-21.

Boyd, C.E. 2003. Guidelines for aquaculture effluent management at the farm-level. Aquaculture, 226:101-112

Isyiagi, N.A., K.L.Veverica, R. Asiimwe, and W.H. Daniels. 2009. Manual for commercial pond production of the African catfish in Uganda, Kampala, p. 222

Iwama, G.K., M.M. Vijayan, and J.D. Morgan. 2000. The stress response in fish. Ichthyology, recent research advances. Oxford and IBH Publishing Co, Pvt. Ltd, New Delhi.

Rohmana, D., E.H. Surawidjaja, S. Sukenda, and J. Ekasari. 2015. Water quality and production performance of catfish-prawn co-culture with organic carbon source addition. Aquaculture International, Vol. 23. Pp: 267-276

Septriani, N.I, Sudarmadji, and Baiquni. 2015. Carrying capacity based on multi-criteria evaluation of marginal land for catfish farming in Gunungkidul Regency, Yogyakarta. International Journal of Chemical, Environmental and Biological Sciences (IJCEBS), Vol. 4. Issue 4

Shoko, A.P., S.M. Limbu, H.D.J. Mrosso, and Y.D. Mgaya. 2014. A comparison of diurnal dynamics of water quality parameters in Nile tilapia (Oreochromis niloticus, Linnaeus, 1758) monoculture and polyculture with African sharp tooth catfish (Clarias gariepinus, Burchell, 1822) in earthen ponds. Int. Aquat. Rest., Vol. 6. 56

Townsend, C.R. and B. Baldisserotto. 2001. Survival of silver catfish fingerlings exposed to acute changes of water $\mathrm{pH}$ and hardness. Aquaculture International, Vol. 9. Pp: 413-419 